\section{Pulse-labelling of Nucleic Acids and Polyphosphates in Normal and Anucleate Cells of Acetabularia}

Following the observation that the DNA and RNA of synchronized cells of Chlorella which have been given pulses of phosphorus-32 in inorganic phosphate are rapidly labelled in certain fractions ${ }^{1}$, we have performed analogous experiments on normal and anucleate cells of Acetabularia. This organism provides a very convenient system for investigation of the synthesis of RNA outside the nucleus, perhaps in the plastids. When we applied the technique of pulse-labelling to cells of Acetabularia crenulata we found that most of the label was incorporated in polyphosphate. We also investigated the distribution of total nucleic acids in normal and anucleate cells and the occurrence of pulse-labelled RNA fractions.

Cells of the marine green alga Acetabularia crenulata were cultured by the methods of Hämmerling ${ }^{2}$ and Beth $^{3}$. Anucleate cells were produced by amputation of the basal rhizoid which contains the nucleus. For pulselabelling experiments samples of 200-300 cells were collected at various times during the light phase and washed and resuspended in sterile sea water. After preillumination with 2,500 lux for $15 \mathrm{~min}$ at $25^{\circ}-26^{\circ} \mathrm{C}$ the cells were given $2-5 \mu \mathrm{c} . / \mathrm{ml}$. of labelled phosphate for 30 or $60 \mathrm{~min}$ in identical conditions. The cells were thoroughly washed with sterile sea water and distilled water respectively and gently disrupted in the cold in a medium of 0.05 molar tris buffer, $p \mathrm{H} 7 \cdot 5$, and 2 mmolar magnesium sulphate. The nucleic acids were isolated and fractionated by chromatography on methylated serum albumin columns as reported earlier ${ }^{4}$.

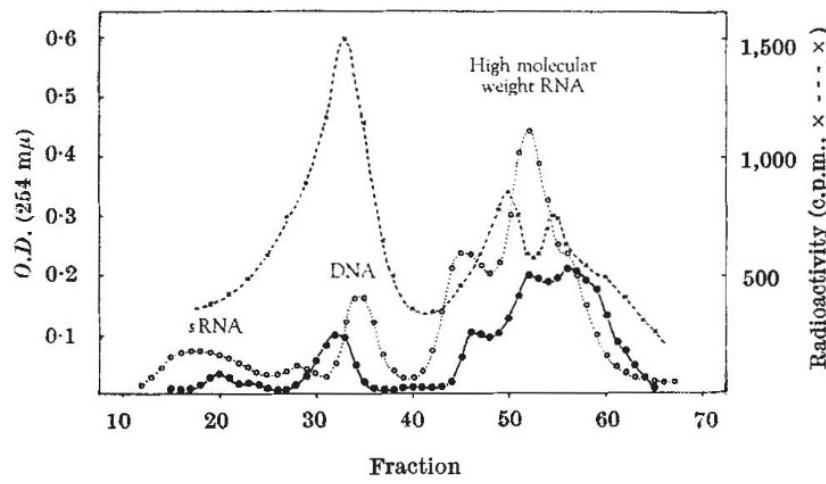

Fig. 1. Fractionation of the nucleic acids from normal cells of Acetabularia crenulata (-) after pulse-labelling with labelled phosphate (5 $\mu \mathrm{c}$. $/ \mathrm{ml}$.) for $30 \mathrm{~min}$ (300 cells, $25-30 \mathrm{~mm}$ stalk length). Chromatography was carried out on methylated serum albumin and kieselguhr, elution was with a logarithmic concentration gradient of sodium chloride from $0 \cdot 1-1 \cdot 5$ molar and $5 \mathrm{ml}$./ tube were collected at room temperature. under identical conditions is given.

Fig. 1 shows a typical chromatographic pattern of nucleic acids from normal cells of Acetabularia crenulata after a $30 \mathrm{~min}$ exposure to labelled phosphate in the light. The ultra-violet absorption profile indicates that the nucleic acids were resolved into the following fractions: soluble RNA, DNA and at least three components of RNA of high molecular weight. The elution pattern corresponds fairly well with that obtained from preparations of Chlorella pyrenoidos $a^{4}$. The profile of radioactivity shows three distinct components; the first shows as a high peak and is eluted together with the bulk DNA; the others appear as smaller peaks just before the main fractions of RNA of high molecular weight. The identification of this RNA is proved by the action of ribonuclease which degraded it to non-sedimentable materials. The highly labelled DNA fraction, however, was stable to ribonuclease and deoxyribonuclease; alkaline hydrolysis with
0.5 molar potassium hydroxide for $18 \mathrm{~h}$ at $38^{\circ} \mathrm{C}$ liberated a labelled acid-soluble product. It was identified as phosphate by means of paper chromatography and autoradiography; only traces of labelled ribonucleotides were detectable. Acid hydrolysis for $7 \mathrm{~min}$ with 1.0 normal hydrochloric acid at $100^{\circ} \mathrm{C}$ degraded the radioactive material of the DNA region almost quantitatively to labelled phosphate. These results suggest that the highly labelled component of the DNA fraction mainly consisted of polyphosphates which were eluted at about the same molarity of sodium chloride as the DNA and so the latter is masked completely by the radioactive poly. phosphates.

Pulse-labelling of anucleate cells resulted in a very similar distribution of radioactivity in the nucleic acids separated by column chromatography (Fig. 2). A high peak of polyphosphates coincided with the chromatographic position of the bulk DNA of normal cells, and two smaller peaks were eluted just before the corresponding fractions of RNA of high molecular weight.

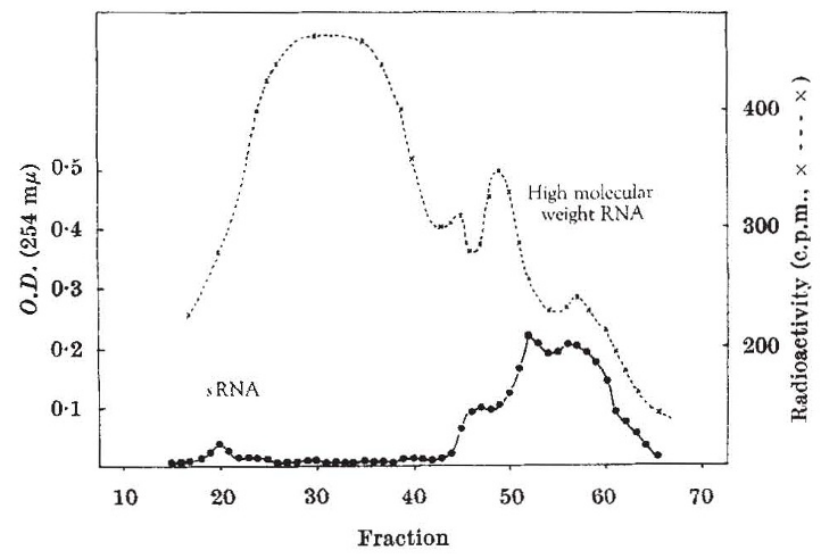

Fig. 2. Fractionation of the nucleic acids from anucleate cells of $A$. crenulata after labelling for $60 \mathrm{~min}(5 \mu \mathrm{c}$./ml.; 200 cells, $25-30 \mathrm{~mm}$ stalk length, 4 days after anucleation). Chromatography as described for Fig. 1. Absorption at $254 \mathrm{~m} \mu$; $\times---x$, c.p.m.

Our findings are in agreement with those reported by Janowski ${ }^{5}$ in that they provide evidence of the existence of rapidly labelled RNA fractions in normal and anucleate cells of Acetabularia. A detailed comparison, however, is impossible, because Janowski used a different fractionation technique on methylated serum albumin, and the results give no information on the chromatographic distribution of the bulk nucleic acids of Acetabularia. The relative stability of the radioactive fractions to the action of ribonuclease and deoxyribonuclease which he reported suggests the presence of labelled polyphosphates in the preparations.

We are incubating normal and anucleate cells of $A$. crenulata for various periods of time with sodium bicarbonate in the light in order to avoid incorporation of label into polyphosphates. Preliminary experiments have revealed radioactive fractions in the region of the DNA and the RNA of high molecular weight on the elution diagram.

This work has been supported by a grant from the Deutsche Forschungsgemeinschaft.

GTRHARD RICHTER

Botanical Institute,

University of Tübingen,

Tübingen, Germany.

1 Richter, G., and Senger, H., Biochim. Biophys. Acta, 95, 362 (1965).

2 Hämmerling, J., Arch. Protistenkunde, 97, 7 (1944).

'Beth, K., Z. Naturforsch., 8b, 334 (1953).

4 Richter, G., and Senger, H., Biochim. Biophys. Acta, 87, 502 (1964)

5 Janowski, M., Biochim. Biophys. Acta, 103, 399 (1965). 